\title{
L-(-)-( $N$-trans-Cinnamoyl)-arginine, an Acylamino Acid from Glinus oppositifolius (L.) Aug. DC.
}

\author{
Poolsak Sahakitpichan ${ }^{1}$, Wannaporn Disadee ${ }^{1}$, Somsak Ruchirawat ${ }^{1,2}$ and \\ Tripetch Kanchanapoom ${ }^{3, *}$
}

1 Chulabhorn Research Institute and Chulabhorn Graduate Institute, Vipavadee-Rangsit Highway, Bangkok 10210, Thailand; E-Mails: poolsak@cri.or.th (P.S.); wannapor@cri.or.th (W.D.)

2 The Center of Excellence on Environmental Health, Toxicology and Management of Chemicals, Vipavadee-Rangsit Highway, Bangkok 10210, Thailand; E-Mail: somsak@cri.or.th

3 Faculty of Pharmaceutical Sciences, Khon Kaen University, Khon Kaen 40002, Thailand

* Author to whom correspondence should be addressed; E-Mail: trikan@kku.ac.th;

Tel.: +66-43-362092; Fax: +66-43-202379.

Received: 28 July 2010; in revised form: 27 August 2010 / Accepted: 30 August 2010 /

Published: 2 September 2010

\begin{abstract}
An amino acid derivative, L-(-)-(N-trans-cinnamoyl)-arginine, was isolated from the whole plant of Glinus oppositifolius (L.) Aug. DC. along with kaempferol 3-Ogalactopyranoside, isorhamnetin 3-O- $\beta$-D-xylopyranosyl-( $1 \rightarrow 2)-\beta$-D-galactopyranoside, vitexin, vicenin-2, adenosine and L-phenylalanine. The structure determinations were based on analyses of chemical and spectroscopic methods.
\end{abstract}

Keywords: Glinus oppositifolius; Molluginaceae; L-(-)-(N-trans-cinnamoyl)-arginine; arginine derivative; flavonol glycoside; flavone $C$-glycoside

\section{Introduction}

Glinus oppositifolius (L.) Aug. DC. (Mollungincaeae; Thai name: Phak-Khee-Khuang) is an annual prostrate weed commonly found in paddy fields after harvesting, especially in the Northeast areas of Thailand. The leaves are used as vegetable for cooking purposes, as well as an expectorant and antipyretic agent. This species has been also found in other tropical parts of Asia, Africa and North Australia. Plants in this genus are reported to contain triterpenoidal saponins [1-6]. In previous studies 
of this plant, triterpenoidal saponins and pectin polysaccharides were reported to act as antiprotozoal [6] and immunomodulating agents [7,8], respectively. The plant extracts showed antifungal, larvicidal, molluscicidal, free scavenging and antioxidant activities $[9,10]$.

The present paper deals with the isolation and characterization of a new amino acid derivative $\mathbf{1}$ from G. oppositifolius, together with six known compounds, including four flavonoid glycosides 2-5, one nucleoside $\mathbf{6}$, and one amino acid $\mathbf{7}$, from the water soluble fraction of the whole plant.

\section{Results and Discussion}

The methanolic extract of $G$. oppositifolius was suspended in $\mathrm{H}_{2} \mathrm{O}$ and partitioned with $\mathrm{Et}_{2} \mathrm{O}$. The aqueous layer was separated by the combinations of Diaion HP20 column, silica gel column, RP-18 column and preparative HPLC-ODS column chromatography to provide seven compounds 1-7.

Figure 1. Structures of isolated compounds 1-7.<smiles>[R]Oc1c(-c2ccc(O)cc2)oc2cc(O)cc(O)c2c1=O</smiles><smiles>[Y4][CH]Oc1c(-c2ccc(O)c(OC)c2)oc2cc(O)cc(O)c2c1=O</smiles><smiles>Nc1ncnc2c1ncn2C1OC2OC1C(O)C2O</smiles><smiles>N[C@@H](Cc1ccccc1)C(=O)O</smiles>

Compound $\mathbf{1}$ was isolated as an amorphous powder. Its molecular formula was determined as $\mathrm{C}_{15} \mathrm{H}_{20} \mathrm{~N}_{4} \mathrm{O}_{3}$ by high-resolution electrospray ionization time-of-flight (ESITOF) mass spectrometric analysis. Inspection of the IR spectrum indicated the presence of the typical amine N-H stretching absorption band at 3333 and $3165 \mathrm{~cm}^{-1}$. The band at $1667 \mathrm{~cm}^{-1}$ is a characteristic for the $\mathrm{C}=\mathrm{O}$ stretching of an amide and a carboxylic acid, $1613 \mathrm{~cm}^{-1}$ for the $\mathrm{C}=\mathrm{N}$ of a quanidyl group, and the $1571 \mathrm{~cm}^{-1}$ one for amine group bending vibrations [11,12]. The ${ }^{1} \mathrm{H}-\mathrm{NMR}$ spectrum exhibited a trans-cinnamoyl moiety inferred from a set of five protons corresponding to an aromatic ring at $\delta_{\mathrm{H}}$ $7.32(2 \mathrm{H}), 7.35(1 \mathrm{H})$ and $7.43(2 \mathrm{H})$, in addition to two olefin protons at $\delta_{\mathrm{H}} 6.74$ and 7.28 (each $d$ ). The trans configuration was assigned from the coupling constant with $J=15.8 \mathrm{~Hz}$. The ${ }^{13} \mathrm{C}-\mathrm{NMR}$ spectrum showed 13 carbon signals (Table 1), of which nine were assignable to a trans-cinnamoyl moiety. The 
remaining carbon signals belong to three methylenes $\left(\delta_{C} 25.5,30.2,40.8\right)$, one methine $\left(\delta_{C} 54.3\right)$ and two quaternary carbons $\left(\delta_{\mathrm{C}} 157.7,176.6\right)$, compatible to those of the amino acid arginine [13]. Therefore, this compound was suggested to be a trans-cinnamoyl derivative of arginine. The complete assignments were established by analyzing the 2D-NMR spectra including COSY, HSQC and HMBC. In the HMBC spectrum (Table 1), the significant correlations were observed between $\delta_{\mathrm{H}} 4.13(\mathrm{H}-2)$ and $\delta_{\mathrm{C}} 164.7$ (C-9'), indicating that one of the hydrogen atoms of the $\alpha$-amino group was replaced by the cinnamoyl moiety. In order to determine the absolute configuration, L- $(-)-(N$-trans-cinnamoyl)arginine $\left([\alpha]_{\mathrm{D}}^{27}-15.8^{\circ}\right.$ in $\left.6 \mathrm{~N} \mathrm{HCl}\right)$ was synthesized by acylation of $\mathrm{L}-(+)$-arginine $\left([\alpha]_{\mathrm{D}}^{27}+24.5^{\circ}\right.$ in $6 \mathrm{~N}$ $\mathrm{HCl})$ with trans-cinnamoyl chloride (see Experimental) [12] to compare the optical rotation value. Since the isolated compound showed the optical rotation value at $[\alpha]_{\mathrm{D}}^{27}-14.9^{\circ}$ in $6 \mathrm{~N} \mathrm{HCl}$, the absolute configuration at C-2 position was concluded to be $(S)$. Consequently, compound 1 was identical to the synthetic compound, L-(-)-(N-trans-cinnamoyl)-arginine. Furthermore, the electron ionization mass spectrometric analysis showed the fragment ions of this compound at $\mathrm{m} / \mathrm{z} 131$ (100), 146 (59), 103 (45), 113 (35) as illustrated in Figure 2. The structure of this compound was initially proposed in 1986 as a synthetic compound for exploration of carboxypeptidase $\mathrm{N}$ functions [14]. The physical and spectroscopic data were given here, and it should be noted that this compound has been reported from the natural sources for the first time.

Table 1. NMR spectroscopic data of compound 1 (in DMSO- $d_{6},{ }^{13} \mathrm{C}-\mathrm{NMR}$ : $100 \mathrm{MHz}$ and ${ }^{1} \mathrm{H}-\mathrm{NMR}$ : $400 \mathrm{MHz}$ ).

\begin{tabular}{lrll}
\hline Position & \multicolumn{1}{c}{$\boldsymbol{\delta}_{\mathbf{C}}$} & $\delta_{\mathbf{H}}$ & HMBC \\
\hline Amino acid & & & \\
1 & 176.6 & & $1,3,4,9^{\prime}$ \\
2 & 54.3 & $4.13(1 \mathrm{H}, m)$ & $1,2,4,5$ \\
3 & 30.2 & $1.62(1 \mathrm{H}, m)$ & $1,2,4,5$ \\
& & $1.75(1 \mathrm{H}, m)$ & $2,3,5$ \\
4 & 25.5 & $1.48(2 \mathrm{H}, m)$ & $3,4,6$ \\
5 & 40.8 & $3.05(2 \mathrm{H}, m)$ & $1,2,3,8^{\prime}, 9^{\prime}$ \\
6 & 157.7 & & \\
$2-\mathrm{NH}$ & & $8.21(1 \mathrm{H}, d, J=8.0 \mathrm{~Hz})$ & $7^{\prime}$ \\
Cinnamoyl moiety & & & $1^{\prime}$ \\
$1^{\prime}$ & 135.5 & & \\
$2^{\prime}, 5^{\prime}$ & 127.8 & $7.43(2 \mathrm{H}, d d, J=8.0,1.7 \mathrm{~Hz})$ & $1^{\prime}, 2^{\prime}, 8^{\prime}, 9^{\prime}$ \\
$3^{\prime}, 6^{\prime}$ & 129.2 & $7.32(2 \mathrm{H}, m)$ & $1^{\prime}, 7^{\prime}, 9^{\prime}$ \\
$4^{\prime}$ & 129.6 & $7.35(1 \mathrm{H}, m)$ & \\
$7^{\prime}$ & 138.4 & $7.28(1 \mathrm{H}, d, J=15.8 \mathrm{~Hz})$ & \\
$8^{\prime}$ & 123.3 & $6.74(1 \mathrm{H}, d, J=15.8 \mathrm{~Hz})$ & \\
$9^{\prime}$ & 164.7 & & \\
\hline
\end{tabular}


Figure 2. Possible major fragment ions of compound 1.

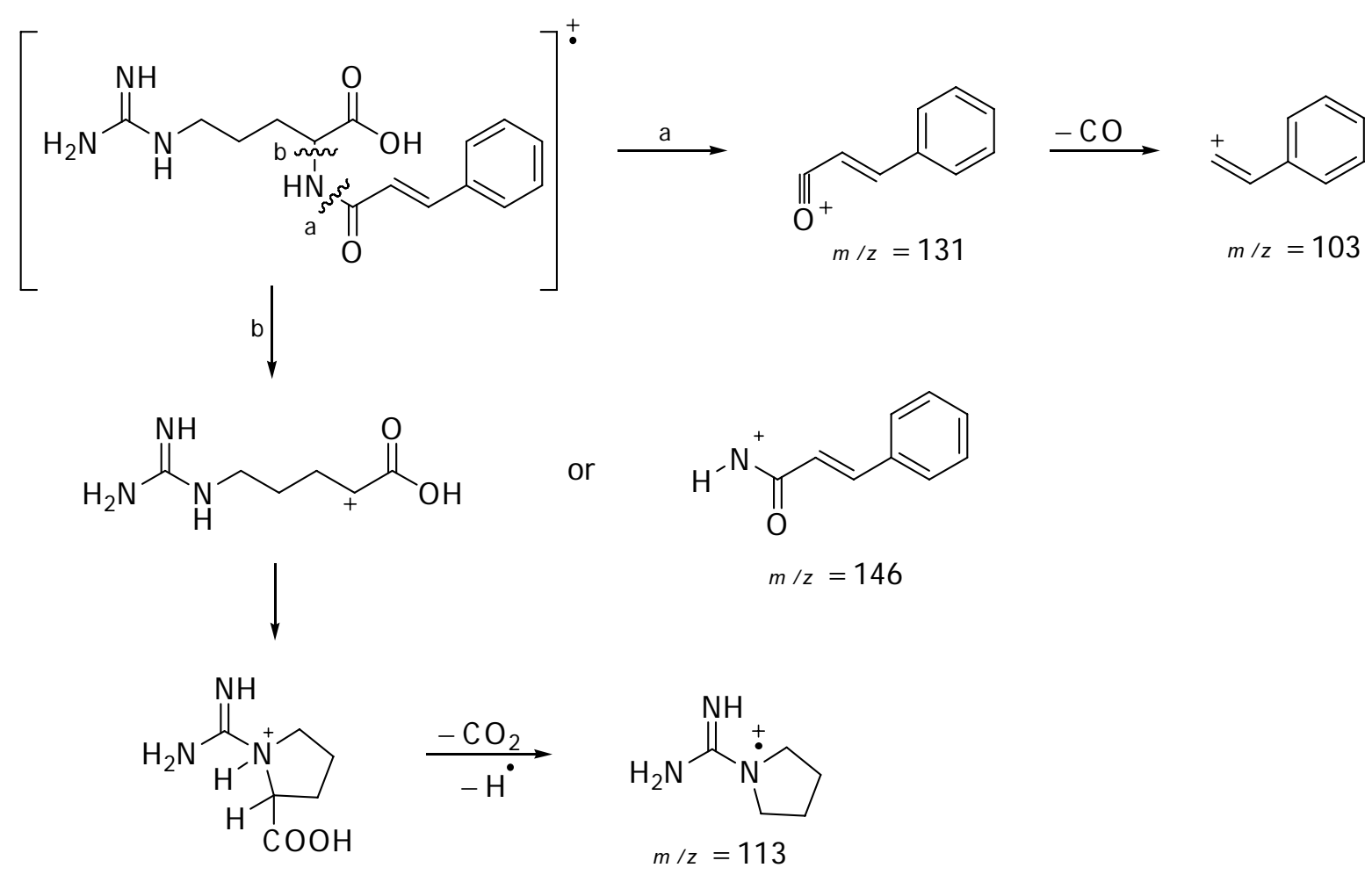

Compounds 2 and 3 were identified as kaempferol 3-O- $\beta$-D-galactopyranoside and isorhamnetin 3-O- $\beta$-D-xylopyranosyl-( $1 \rightarrow 2)$ - $\beta$-D-galactopyranoside, respectively. $[15,16]$ The NMR spectroscopic data of compounds 4 and 5 were coincident with those of apigenin 8-C- $\beta$-D-glucopyranoside (vitexin) and apigenin 6,8-di-C- $\beta$-D-glucopyranoside (vicenin-2), respectively. [17,18] Compounds 6 and 7 were assigned to adenosine and L-phenylalanine, respectively, by comparison of physical and NMR spectral data with authentic samples [19].

\section{Experimental}

\subsection{General}

${ }^{1} \mathrm{H}$ - and ${ }^{13} \mathrm{C}-\mathrm{NMR}$ spectra were recorded in DMSO- $d_{6}$ using a Bruker AV-400 (400 MHz for ${ }^{1} \mathrm{H}-\mathrm{NMR}$ and $100 \mathrm{MHz}$ for $\left.{ }^{13} \mathrm{C}-\mathrm{NMR}\right)$ or a Varian Gemini $2000\left(200 \mathrm{MHz}\right.$ for ${ }^{1} \mathrm{H}-\mathrm{NMR}$ and $50 \mathrm{MHz}$ for ${ }^{13} \mathrm{C}$-NMR) spectrometer. IR spectra were obtained from a Perkin Elmer Universal FTIR spectrometer. Low resolution mass spectrometry (LRMS) was performed using a Finnigan Polaris mass spectrometer. High resolution mass spectrometry (HRMS) was performed using a Bruker Micro TOF-LC mass spectrometer. Optical rotations were measured with a Jasco P-1020 digital polarimeter. For column chromatography, Diaion HP-20 (Mitsubishi Chemical Industries Co. Ltd.), silica gel 60 (70-230 mesh, Merck), and RP-18 (50 $\mu \mathrm{m}$, YMC) were used. HPLC was carried out on an ODS column (20 X $250 \mathrm{~mm}$ i.d., YMC) with a Jasco RI-2031 refractive index detector. The flow rate was $6 \mathrm{~mL} / \mathrm{min}$. The solvent systems were: I) EtOAc-MeOH (9:1); II) EtOAc-MeOH-H ${ }_{2} \mathrm{O}$ (40:10:1); III) EtOAc- $\mathrm{MeOH}-\mathrm{H}_{2} \mathrm{O}$ (70:30:3); IV) EtOAc-MeOH-H${ }_{2} \mathrm{O}$ (6:4:1); V) 10-80\% aqueous $\mathrm{MeOH}$; VI) 2\% 
aqueous MeCN; VII) 5\% aqueous MeCN; VIII) 15\% aqueous MeCN; and IX) 20\% aqueous MeCN. The spraying reagent used for TLC was $10 \% \mathrm{H}_{2} \mathrm{SO}_{4}$ in $50 \% \mathrm{EtOH}$.

\subsection{Plant Material}

Glinus oppositifolius (L.) Aug. DC. was collected in January 2008 from Khon Kaen province, Thailand. The plant was identified by Mr. Nopporn Nontapa of Department of Pharmaceutical Botany and Pharmacognosy, Faculty of Pharmaceutical Sciences, Khon Kaen University. A voucher specimen (TK-PSKKU-0063) has been deposited in the Herbarium of the Faculty of Pharmaceutical Sciences, Khon Kaen University.

\subsection{Extraction and Isolation}

Dried whole Glinus oppositifolius $(1.4 \mathrm{~kg})$ was extracted three times with $\mathrm{CH}_{3} \mathrm{OH}(8 \mathrm{~L}$ for each extraction) at room temperature. The solvent was concentrated in vacuo to give a greenish powder (226.4 g). This residue was suspended in $\mathrm{H}_{2} \mathrm{O}$ and defatted with $\mathrm{Et}_{2} \mathrm{O}$ three times $(1 \mathrm{~L}$ each). The aqueous soluble fraction (113.6 g) was applied to a column of Diaion HP-20 and eluted successively with $\mathrm{H}_{2} \mathrm{O}, \mathrm{CH}_{3} \mathrm{OH}$, and $\left(\mathrm{CH}_{3}\right)_{2} \mathrm{CO}$. The fraction eluted with $\mathrm{CH}_{3} \mathrm{OH}(20.0 \mathrm{~g})$ was concentrated to dryness and subjected to a silica gel column using solvent systems I (4.0 1), II (4.0 1), III (6.0 1) and IV (5.0 1) providing six fractions (fraction A-F). Fraction B (2.6 g) was applied to a column of RP-18 using solvent system $\mathrm{V}$ to give 12 fractions. Fraction B-8 was purified by preparative HPLC-ODS with solvent system IX to afford compound $2(10.9 \mathrm{mg})$. Fraction B-11 was purified by preparative HPLC-ODS with solvent system IX to give compound 4 (73.1 mg). Fraction C (3.2 g) was separated on a column of RP-18 using solvent system V to give nine fractions. Compound 6 (40.1 mg) was obtained from fraction C-3 by crystallization. Fraction D (5.0 g) was subjected to a column of RP-18 using solvent system V to give 12 fractions. Fractions D-3 and D-4 were combined and purified by preparative HPLC-ODS with solvent system VIII to afford compound 5 (317.3 $\mathrm{mg}$ ). Fraction D-9 was further purified by preparative HPLC-ODS to yield compound $3(13.0 \mathrm{mg})$. Fraction E (3.4 g) was chromatographed on a column of RP-18 using solvent system V to provide six fractions. Fraction E-1 was purified by preparative HPLC-ODS with solvent system IX to give compound 7 (31.7 $\mathrm{mg}$ ). Finally, fraction E-4 was purified by preparative HPLC-ODS with solvent system VIII to obtain compound 1 (115.0 mg).

\subsection{L-(-)-(N-trans-cinnamoyl)-Arginine (1).}

Amorphous powder: $[\alpha]_{\mathrm{D}}^{27}-14.9^{\circ}\left(6 \mathrm{~N} \mathrm{HCl}\right.$, c 0.22); IR (UATR) $v_{\max } 3333,3165,3047,1667,1613$, 1571, 1400, 1245, $979 \mathrm{~cm}^{-1}$; ${ }^{1} \mathrm{H}$ - and ${ }^{13} \mathrm{C}-\mathrm{NMR}$ (DMSO-d ${ }_{6}$ ): Table 1; EIMS: $\mathrm{m} / \mathrm{z} 131$ (100), 146 (59), 103 (45), 113 (35); Negative HRMS(ESITOF), m/z: $303.1468[\mathrm{M}-\mathrm{H}]^{-}$(calcd for $\mathrm{C}_{15} \mathrm{H}_{19} \mathrm{~N}_{4} \mathrm{O}_{3}$, 303.1463).

\subsection{Synthesis of L-(-)-(N-trans-cinnamoyl)-Arginine (1)}

L-(+)-Arginine $(50.2 \mathrm{mg})$ was dissolved in $\mathrm{H}_{2} \mathrm{O}(2.0 \mathrm{~mL})$ and the $\mathrm{pH}$ adjusted to 12.0 with $2 \mathrm{~N} \mathrm{NaOH}$. A solution of trans-cinnamoyl chloride $(51.5 \mathrm{mg})$ in dioxane $(2.0 \mathrm{~mL})$ was added. After stirring at 
room temperature for $30 \mathrm{~min}$, the reaction was concentrated and purified by preparative HPLC-ODS with solvent system VIII to obtain L-(-)-( $N$-trans-cinnamoyl)-arginine $(15.0 \mathrm{mg})$ as an amorphous powder, $[\alpha]_{\mathrm{D}}^{27}-15.8^{\circ}(6 \mathrm{~N} \mathrm{HCl}, c 0.12)$. The NMR spectroscopic data was identical to those of the natural compound.

\section{Conclusions}

Isolated compounds of Thai plant origin were described as an acylamino acid 1, flavonoid glycosides 2-5, a nucleoside 6, and an amino acid 7. The results of our study were different from the previous mention on the chemical constituents of genus Glinus, indicating triterpenoidal saponins. The chemical variations might be due to the different geographical regions involved. The study identified new types of compounds in this species.

\section{Acknowledgements}

This study was financially supported by Chulabhorn Research Institute and the Center of Excellence on Environmental Health, Toxicology and Management of Chemicals, Thailand.

\section{References}

1. Hamed, A.I.; Springuel, I.; El-Emary, N.A.; Mitome, H.; Miyaoka, H.; Yamada, Y. Triterpenoidal saponin glycosides from Glinus lotoides var. dictamnoides. Phytochemistry 1996, 43, 183-188.

2. Hamed, A.I.; El-Emary, N.A. Triterpene saponins from Glinus lotoides var. dictamnoides. Phytochemistry 1999, 50, 477-480.

3. Endale, A.; Wray, V.; Murillo, R.; Schmidt, P.C.; Merfort, I. Hopane-type saponins from the seeds of Glinus lotoides. J. Nat. Prod. 2005, 68, 443-446.

4. Biswas, T.; Gupta, M.; Achari, B.; Pal, B.C. Hopane-type saponins from Glinus lotoides Linn. Phytochemistry 2005, 66, 621-626.

5. Hamed, A.I.; Piacente, S.; Autore, G.; Marzocco, S.; Pizza, C.; Oleszek, W. Antiproliferative hopane and oleanane glycosides from the roots of Glinus lotoides. Planta Med. 2005, 71, 554-560.

6. Traore, F.; Faure, R.; Ollivier, E.; Gasquet, M.; Azas, N.; Debrauwer, L.; Keita, A.; Timon-David, P.; Balansard, G. Structure and antiprotozoal activity of triterpenoid saponins from Glinus oppositifolius. Planta Med. 2000, 66, 368-371.

7. Inngjerdingen, K.T.; Debes, S.C.; Inngjerdingen, M.; Hokputsa, S.; Harding, S.E.; Rolstad, B.; Michaelsen, T.E.; Diallo, D.; Paulsen, B.S. Bioactive pectic polysaccharides from Glinus oppositifolius (L.) Aug. DC., a Malian medicinal plant, isolation and partial characterization. J. Ethnopharmacol. 2005, 101, 204-214.

8. Inngjerdingen, K.T.; Kiyohara, H.; Matsumoto, T.; Petersen, D.; Michealsen, T.E.; Diallo, D.; Inngjerdingen, M.; Yamada, H.; Paulsen B.S. An immunomodulating pectic polymer from Glinus oppositifolius. Phytochemistry 2007, 68, 1046-1058. 
9. Diallo, D.; Marston, A.; Terreaux. C.; Touré, Y.; Paulsen, B.S.; Hostettmann, K. Screening of Malian Plants for antifungal, latvicidal, molusscicidal, antioxidant and radical scavenging activities. Phytother. Res. 2001, 15, 401-406.

10. AsokKumar, K.; UmaMaheswari, M.; Sivashanmugam, A.T.; SubhadraDevi, V.; Subhashini, N. Free radical scavenging and antioxidant activities of Glinus oppositifolius (carpet weed) using different in vitro assay systems. Pharmaceut. Biol. 2009, 47, 474-482.

11. Silverstein, R.M.; Bassler, G.C.; Morrill, T.C. Spectrometric Identification of Organic Compounds, 5th ed.; John Wiley \& Sons, Inc.: New York, NY, USA, 1991; pp. 91-164.

12. Pretsch, E.; Bühlmann, P.; Affolter, C. Structure Determination of Organic Compounds: Table of Spectral Data, 3rd ed.; Springer: New York, NY, USA, 2000; pp. 71-160, 245-312.

13. Wauven, A.V.; stalon, V. Occurrence of succinyl derivatives in the catabolism of arginine in Pseudomonas cepacia. J. Bacteriol. 1985, 164, 882-886.

14. Fisher, G.H.; Ryan, J.W.; Chung, A.; Plumer, T.H., Jr. Synthetic inhibitors of carboxypeptidase N. Adv. Exp. Med. Biol. 1986, 198A, 405-410.

15. Barberá, O.; Sanz, J.F.; Sánchez-Parareda, J.; Marco, J.A. Further flavonol glycosides from Anthyllis onobrychioides. Phytochemistry 1986, 25, 2361-2365.

16. Sikorska, M.; Matlawska, I. Kaempferol, isorhamnetin and their glycosides in the flowers of Asclepias syriaca L. Acta Pol. Pharm. 2001, 58, 269-272.

17. Agrawal, P.K.; Bansal, M.C. Carbon-13 NMR of flavonoids. In Flavonoid Glycosides; Agrawal, P.K., ed.; Elsevier: Amsterdam, Netherlands, 1986; pp. 283-336.

18. Kanchanapoom, T.; Kasai, R.; Yamasaki, K. Iridoid glucosides from Tunbergia laurifolia. Phytochemistry 2002, 60, 769-771.

19. Kanchanapoom, T.; Kamel, M.S.; Kasai, R.; Picheansoonthon, C.; Hiraga, Y.; Yamasaki, K. Benzoxazinoid glucosides from Acanthus ilicifolius. Phytochemistry 2001, 58, 637-640.

Sample Availability: Samples of the compounds are available from the authors.

(C) 2010 by the authors; licensee MDPI, Basel, Switzerland. This article is an Open Access article distributed under the terms and conditions of the Creative Commons Attribution license (http://creativecommons.org/licenses/by/3.0/). 